\title{
Combined Drying of Apple Cubes by Using of Heat Pump, Vacuum-Microwave, and Intermittent Techniques
}

\author{
Chien Hwa Chong • Adam Figiel • Chung Lim Law • \\ Aneta Wojdylo \\ Received: 9 December 2012 / Accepted: 1 May 2013 /Published online: 26 May 2013 \\ (C) The Author(s) 2013. This article is published with open access at Springerlink.com
}

\begin{abstract}
Apple cubes of $15 \mathrm{~mm}$ were dried naturally without adding any chemical preservative using various drying methods namely intermittent hot air-dehumidified air drying with cyclic temperature profile and step-up temperature profile, heat-pump-assisted (HP) drying, convective vacuum-microwave $(\mathrm{C} / \mathrm{VM})$ drying, and heat pump vacuum-microwave (HP/VM) drying. The drying kinetics of apple samples dehydrated by different methods was divided into characteristic drying periods and fitted with empirical models, which gave high value of determination coefficient. The application of $\mathrm{C} / \mathrm{VM}$ in drying of fruits gave the shortest drying time compared to other drying methods (about $50 \%$ of the total drying time). The drying time was affected by effective diffusivity ranging from $3.522 \times 10^{-8}$ to $1.431 \times 10^{-6} \mathrm{~m}^{2} / \mathrm{min}$ depending on the drying technique used. It was found that combined drying which apply vacuum microwave (C/VM, HP/VM) gave the lowest values in hardness and chewiness. In addition, HP/VM drying gave the highest retained total polyphenol content, antioxidant activity, and the best appearance quality.
\end{abstract}

\section{H. Chong}

School of Engineering, Taylor's University,

Lakeside Campus, No1, Jalan Taylor's,

47500, Subang Jaya, Selangor, Malaysia

A. Figiel

Institute of Agricultural Engineering, Wroclaw University of Environmental and Life Sciences, Chełmońskiego 37/41 Street, Wroclaw 51-630, Poland

C. L. Law

Faculty of Chemical and Environmental Engineering,

The University of Nottingham, Malaysia Campus, Broga Road,

43500, Semenyih, Selangor Darul Ehsan, Malaysia

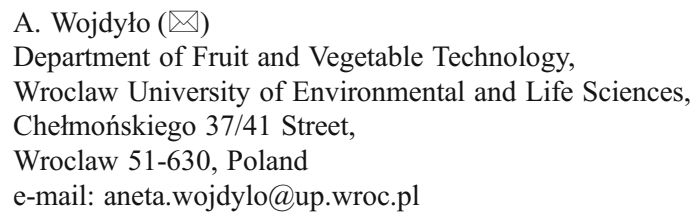

Keywords Drying · Heat pump · Vacuum microwaves · Texture $\cdot$ Polyphenols · Antioxidant activity $\cdot$ Physical appearance

\section{Introduction}

In fruit processing industry, drying is applied to produce a variety of dehydrated fruits. Minimizing the adverse effects of processing on the quality of the dehydrated fruit is a major concern. Commercial dehydrated fruit products typically processed by conventional drying technique which normally takes about $24 \mathrm{~h}$ to complete, while the product quality in terms of visual, textural attributes, and the content of healthpromoting ingredients is not always guaranteed. It is very much dependent on the selection of dryer (Leite et al. 2007). Often the appearance of the dehydrated product becomes darker or brownish because of browning reactions occur during the drying process (Erenturk et al. 2004). Many attempts have been carried out by researchers in order to improve the product quality such as minimizing color change, maximizing the retention of bio-active ingredients, and etc. Table 1 summarizes the research findings reported on the drying of apple, it can be seen that majority reported on drying kinetics.

The application of microwave-assisted drying (either coupled with convective hot air drying, or freeze drying) has been reported to have shortened the drying duration appreciably if compared with convective hot air drying. Quality attributes such as color change and retention of bio-active ingredients, aroma compounds, etc. can be enhanced with microwave-assisted freeze drying (Contreras et al. 2008; Huang et al. 2012). Convective vacuum-microwave drying can reduce the processing time because of large vapor pressure differential between the core and the surface of the dried material which allows rapid removal of internal moisture, whereas microwaves stimulate vibration of water (resulting in internal heat generation) by penetrating through the entire samples. According to Soysal et al. (2009), the use of microwave alone in drying is 
Table 1 References regarding apples dried by different methods

\begin{tabular}{|c|c|c|c|c|}
\hline Drying method & Drying condition & Drying kinetics & Quality & References \\
\hline $\begin{array}{l}\text { Convective drying } \\
\text { cum microwave } \\
\text { drying }\end{array}$ & $\begin{array}{l}\text { Drying temperature: } \\
105^{\circ} \mathrm{C} \text {; power: } 150 \text {, } \\
300,450 \text {, and } 600 \mathrm{~W}\end{array}$ & $\begin{array}{l}\text { Pre-drying with convective hot air } \\
\text { can shorten the drying duration }\end{array}$ & & Wang et al. (2007) \\
\hline Microwave drying & & $\begin{array}{l}\text { Effective diffusivity for convective } \\
\text { drying cum microwave drying } \\
\text { and microwave drying are } \\
2.99 \times 10^{-8}-9.15 \times 10^{-8} \mathrm{~m}^{2} / \mathrm{s} \\
\text { and } 1.05 \times 10^{-8}-3.69 \times 10^{-8} \mathrm{~m}^{2} / \mathrm{s} \text {, } \\
\text { respectively }\end{array}$ & & \\
\hline $\begin{array}{l}\text { Microwave-assisted } \\
\text { air dehydration } \\
\text { Hot air drying }\end{array}$ & $\begin{array}{l}\text { Drying air temperature: } \\
40,60 \text {, and } 80^{\circ} \mathrm{C} \text {; air } \\
\text { velocity: } 0.5,1.0 \text {, and } \\
1.5 \mathrm{~m} / \mathrm{s} \text {. Power: } 0.6 \text { to } \\
1 \mathrm{~W} /(\mathrm{g} \text { of food })\end{array}$ & $\begin{array}{l}\text { Microwave-assisted hot air drying } \\
\text { can reduce the } 50 \% \text { of total hot } \\
\text { air drying time }\end{array}$ & $\begin{array}{l}\text { Uneven heating in microwave } \\
\text { ovens caused browning of } \\
\text { product }\end{array}$ & $\begin{array}{l}\text { Funebo and } \\
\text { Ohlsson (1998) }\end{array}$ \\
\hline $\begin{array}{l}\text { Microwave-assisted } \\
\text { air dehydration } \\
\text { Hot air drying } \\
\text { Vacuum impregnation }\end{array}$ & $\begin{array}{l}\text { Drying air temperature: } \\
30 \text { and } 50{ }^{\circ} \mathrm{C} \text {; air } \\
\text { velocity: } 2.5 \mathrm{~m} / \mathrm{s} \text {. Power: } \\
0.5 \mathrm{~W} /(\mathrm{g} \text { of food })\end{array}$ & $\begin{array}{l}\text { Microwave-assisted hot air drying } \\
\text { reduced the } 55-87 \% \text { of total } \\
\text { hot air drying time. Vacuum } \\
\text { impregnation increased the } \\
\text { convective drying time by up } \\
\text { to } 10 \% \text {, and has any effect on }\end{array}$ & $\begin{array}{l}\text { Longer drying time and } \\
\text { vacuum impregnation resulted in } \\
\text { greater color changing. Vacuum } \\
\text { impregnation and microwaves } \\
\text { promoted firmness and rigidity } \\
\text { of the dried samples }\end{array}$ & $\begin{array}{l}\text { Funebo and } \\
\text { Ohlsson (1998) }\end{array}$ \\
\hline
\end{tabular}

Heat pump drying Solar drying

Radiation ${ }^{60} \mathrm{Co} \gamma$-ray

Hot air drying

Hot air drying

Hot air drying

Hot air drying
Osmotic
dehydration
followed by
air drying

Osmodehydrofreezing
Thickness: $4 \mathrm{~mm}$; mass air velocity: 2.9 to $3.3 \mathrm{~kg} / \mathrm{m}^{2} \mathrm{~s}$

Dosages of irradiation: $0,2,5$, and $6 \mathrm{KGY}$; air velocity: $1.8 \mathrm{~m} / \mathrm{s}$; thickness: 3,5 , and $7 \mathrm{~mm}$

Drying temperature: 40,50 , and $60{ }^{\circ} \mathrm{C}$; thickness : 5 to $9 \mathrm{~mm}$

Drying temperature: $60{ }^{\circ} \mathrm{C}$; air velocity: $0.64,1,1.5,2,2.5$, and $2.75 \mathrm{~m} / \mathrm{s}$.

Thickness: $5 \mathrm{~mm}$

Drying temperature: 33,45 , and $55{ }^{\circ} \mathrm{C}$; air velocity: $0.2,0.4$, and $0.6 \mathrm{~m} / \mathrm{s}$; relative humidity: 40,55 , and $70 \%$

Drying temperature: 30 to $90{ }^{\circ} \mathrm{C}$ at $10{ }^{\circ} \mathrm{C}$ interval. Solution: sucrose, 70 Brix $\left(50{ }^{\circ} \mathrm{C}\right)$; duration: $30,60,90,120$, and $180 \mathrm{~min}$

Drying temperature: $50{ }^{\circ} \mathrm{C}$; duration: microwave-assisted convective drying time

Drying rates of heat pump drying method is higher compared to solar drying method. Effective diffusivity values of heat pump drying and solar drying were $2.36 \times 10^{-8}$ and $1.03 \times 10^{-8} \mathrm{~m}^{2} / \mathrm{s}$, respectively

Irradiation could enhance the drying rates of apple

Effective diffusivity values were ranged from $2.27 \times$ $10^{-10}-4.97 \times 10^{-10} \mathrm{~m}^{2} / \mathrm{s}$

Moisture removal rate increased at elevated velocity. Effective diffusivity values were ranged from $1.79 \times$ $10^{-9}-4.45 \times 10^{-9} \mathrm{~m}^{2} / \mathrm{s}$

Fick's diffusion model was the best fit model and activation energy obtained were ranged from 19.96-22.62 $\mathrm{KJ} \mathrm{mol}^{-1}$. Effective diffusivity values were ranged from $0.48 \times$ $10^{-10}-2.02 \times 10^{-10} \mathrm{~m}^{2} / \mathrm{s}$

The duration of osmotic dehydration did not show significant influence on the diffusivity value. The effective diffusivity values for hot air drying and osmotic cum hot air drying were ranged from $3.21 \times 10^{-10}-12.67 \times 10^{-10}$ and $1.98 \times 10^{-10}-9.79 \times 10^{-10}$, respectively
Aktaş et al. (2009)

Irradiation damaged and changed the apple cell structure

Drying at $60{ }^{\circ} \mathrm{C}$ produce dark slices samples. The best hot air drying temperature was $40{ }^{\circ} \mathrm{C}$ in drying of apple

Sacilik and Elicin (2006)

Velić et al. (2004)

Kaya et al. (2007)

Simal et al. (1997)
Tregunno and Goff (1996) 
Table 1 (continued)

\begin{tabular}{|c|c|c|c|c|}
\hline Drying method & Drying condition & Drying kinetics & Quality & References \\
\hline & $\begin{array}{l}40 \mathrm{~min} \text {; frozen } \\
\text { temperature: }-35{ }^{\circ} \mathrm{C}\end{array}$ & & $\begin{array}{l}\text { of rehydrated tissue } \\
\text { compared with apples } \\
\text { without sugar treatment }\end{array}$ & \\
\hline $\begin{array}{l}\text { Osmotic } \\
\text { dehydration } \\
\text { followed by } \\
\text { convective drying }\end{array}$ & $\begin{array}{l}\text { Drying temperature: } \\
30{ }^{\circ} \mathrm{C} \text {; size: } 10 \mathrm{~mm}^{3} \text {; } \\
\text { pretreatment: } 0.5 \% \text {; } \\
\text { citric acid solution: } \\
61.5 \% \text {; sucrose } \\
\text { duration: } 3 \mathrm{~h}\end{array}$ & & $\begin{array}{l}\text { Presence of concentrated } \\
\text { viscous liquid becomes more } \\
\text { susceptible to deformation } \\
\text { than apple dried by convection }\end{array}$ & $\begin{array}{l}\text { Lewicki and } \\
\text { Lukaszuk (2000) }\end{array}$ \\
\hline Infrared drying & $\begin{array}{l}\text { Drying temperature: } \\
50 \text { to } 80{ }^{\circ} \mathrm{C} \text {; frequency: } \\
50-60 \mathrm{~Hz}\end{array}$ & $\begin{array}{l}\text { Midilli model was the best } \\
\text { fit model for drying kinetics } \\
\text { of infrared dried apple }\end{array}$ & & Toğrul (2005) \\
\hline Infrared drying & $\begin{array}{l}\text { Drying temperature: } \\
\quad 40,60 \text {, and } 70{ }^{\circ} \mathrm{C}\end{array}$ & & $\begin{array}{l}\text { Shrinkage effect can be clearly } \\
\text { seen from infrared dried apple. } \\
\text { In addition, ascorbic acid } \\
\text { degrades with increases drying } \\
\text { temperature. The aroma volatiles } \\
\text { content was found affected by } \\
\text { drying duration and temperature }\end{array}$ & $\begin{array}{l}\text { Timoumi } \\
\text { et al. (2007) }\end{array}$ \\
\hline Freeze drying & $\begin{array}{l}\text { Freezing temperature: } \\
-20{ }^{\circ} \mathrm{C}(49.5 \mathrm{~h}) \\
\text { and }-80{ }^{\circ} \mathrm{C}(50.5 \mathrm{~h})\end{array}$ & $\begin{array}{l}\text { Response surface methodology } \\
\text { (RSM) shows that the optimum } \\
\text { operating pressure was } 50 \mathrm{~Pa} \\
\text { and a heating plate temperature } \\
\text { of } 55^{\circ} \mathrm{C}\end{array}$ & $\begin{array}{l}\text { Texture losses of rehydrated } \\
\text { apple were about } 85 \%\end{array}$ & $\begin{array}{l}\text { Hammami } \\
\text { et al. (1999) }\end{array}$ \\
\hline $\begin{array}{l}\text { Freeze drying (FD) } \\
\text { Combination of freeze- } \\
\text { drying and microwave- } \\
\text { vacuum drying } \\
\text { (FD+MWVD and } \\
\text { MWVD+FD) }\end{array}$ & $\begin{array}{l}\text { Freezing temperature: } \\
-40^{\circ} \mathrm{C} \text { and pressure: } \\
100 \mathrm{~Pa} \text { during } \mathrm{FD}, \\
\text { power: } 1 \mathrm{~W} /(\mathrm{g} \text { of food }) \\
\text { and pressure: } 5 \mathrm{kPa} \\
\text { during } \mathrm{MWVD}\end{array}$ & & $\begin{array}{l}\text { FD+MWVD ensured the best } \\
\text { crispiness and cell structure as } \\
\text { well as the highest total pheols } \\
\text { content in the dried product, } \\
\text { but lower aroma retention } \\
\text { when compared with FD. The } \\
\text { lowest aroma retention exhibited } \\
\text { MWVD+FD samples }\end{array}$ & $\begin{array}{l}\text { Huang } \\
\text { et al. (2012) }\end{array}$ \\
\hline Fluidized bed drying & $\begin{array}{l}\text { Drying temperature: } \\
22^{\circ} \mathrm{C} \text {; air velocity: } \\
18 \mathrm{~L} / \mathrm{s}\end{array}$ & $\begin{array}{l}\text { Final moisture content of } \\
\text { freeze-dried samples is lower } \\
\text { than fluidized bed drying }\end{array}$ & $\begin{array}{l}\text { Nuclear magnetic resonance } \\
\text { (NMR) analysis shows that } \\
\text { the membrane integrity was } \\
\text { destroyed and causes cell } \\
\text { wall collapse }\end{array}$ & $\begin{array}{l}\text { Hills and } \\
\text { Remigereau } \\
(1997)\end{array}$ \\
\hline
\end{tabular}

known to yield a low-quality product. Therefore, microwave is often combined with other drying method. For example convective microwave drying, vacuum microwave drying, etc. In this study, apart from two-stage convective cum microwave drying (C/VM), two-stage heat-pump-assisted drying cum vacuum-microwave drying (HP/VM) was applied. Thus far, the two-stage heatpump-assisted drying cum vacuum-microwave drying has not been reported in the literature.

Apart from microwave-assisted drying, radiation of ${ }^{60} \mathrm{Co} \gamma$-ray can be applied to enhance drying kinetics, however it has been reported that it could damage and change the apple cell structure (Wang and Chao 2002).

With reference to drying of apples, heat-pumpassisted drying was reported to give higher drying rate than solar drying. On the other hand, osmotic dehydration has been applied with convective hot air drying, although the effect of osmotic dehydration on drying kinetics is not evident, but it has affected the textural properties of the dehydrated apples. Meanwhile, infrared drying has been reported to give appreciable effect on the product texture.

Thus far, intermittent drying technique and varying temperature profile have not been reported on the drying of apples, therefore this study also included the study of the effect of intermittent hot air-dehumidified air drying (cyclic temperature profile (CTP)) and step-up temperature profile on the drying kinetics as well as the product quality of apple drying. It is hypothesized that the application of intermittent drying techniques may increase the moisture removal from the interior to the surface during tempering. Thereby enhances the evaporation of surface moisture in the subsequent active drying, thus improving the drying rate. Although the overall drying time is longer compared to continuous drying, its active drying time is shorter. It has been reported that intermittent drying of 
guava, banana, and potato could produce better product quality (Chua et al. 2000).

With reference to the findings and research gaps mentioned above as well as the summary given in Table 1, this study aimed to investigate the effect of the proposed drying techniques such as two-stage heatpump-assisted drying cum vacuum microwave drying and intermittent hot air-dehumidified air (CTP) and step-up temperature drying (STP) on the drying kinetics and the product quality such as textural attributes, appearance, antioxidant activity, and total polyphenol content. The findings of these drying techniques were compared to heat-pump-assisted drying (HP) and convective cum vacuum-microwave drying $(\mathrm{C} / \mathrm{VM})$.

\section{Materials and Methods}

\section{Chemicals}

DPPH (1,1-diphenyl-2-picrylhydrazyl radical), Trolox (6-hydroxy-2,5,7,8-tetramethylchroman-2-carboxylic acid), and methanol were purchased from Sigma-Aldrich (Steinheim, Germany). Gallic acid was purchased from Extrasynthese (Lyon, France). Folin-Ciocalteu and sodium carbonate were from Merck (Darmstadt, Germany).

\section{Samples Preparation}

Apple fruits (Malus domestica; Gala cv) were purchased from a local fruit supplier (Semenyih, Selangor, Malaysia). The fruits were cut into cubes of $15 \mathrm{~mm}$ using a stainless steel knife. The initial moisture content of fresh samples was $8.18 \mathrm{~g} \mathrm{H}_{2} \mathrm{O} / \mathrm{g} \mathrm{dm}$. The moisture content of both fresh and dried samples was determined by the vacuum-oven method (Figiel 2010). The drying duration and operating temperature were $24 \mathrm{~h}$ and $60^{\circ} \mathrm{C}$, respectively.
Drying Process

\section{Convective Pre-drying}

The apple samples were dried in an oven (Memmert, D06836, Germany) at $70{ }^{\circ} \mathrm{C}$. The relative humidity of hot air measured by a hygrometer (HygroFlex, RS232, USA) was $4.6 \%$. The velocity of the air approaching to the sample was measured by an anemometer (Rotronic, D5-U-2, USA) and the average velocity was $0.965 \pm 0.02 \mathrm{~m} / \mathrm{s}$. The samples were placed on a perforated tray, which was located at the centre of the oven. The direction of the air flux was perpendicular to the oven door.

The weight loss of the samples was recorded using an electronic balance (Adventure OHAUS, AR3130, USA) with a range of $0-310 \mathrm{~g}$ and system error of $\pm 0.001 \mathrm{~g}$. The measurement was performed at an interval of $30 \mathrm{~min}$ for the first $60 \mathrm{~min}$ of drying, followed by hourly interval until the moisture content decreased to $1.05 \mathrm{~g} \mathrm{H}_{2} \mathrm{O} / \mathrm{g} \mathrm{dm}$.

\section{Vacuum-Microwave Drying}

Apple cubes that were pre-dried using convective air drying were finish dried in the vacuum-microwave dryer SM-200 (Wrocław, Plazmatronika, Poland; Fig. 1). The samples were placed in a container made of organic glass with volume of $0.0068 \mathrm{~m}^{3}$. This container was connected to a vacuum system, which consists of vacuum pump ("Tepro", Koszalin BL 30P, Poland), vacuum gauge ("Elvac", Bobolice MP 211, Poland), and compensation reservoir with volume of $0.15 \mathrm{~m}^{3}$. The pressure in the container was varied from 4 to $6 \mathrm{kPa}$. The rotation speed of the container was $6 \mathrm{rpm}$. An electric fan installed at the bottom of the dryer produced an air stream of temperature and velocity $22{ }^{\circ} \mathrm{C}$ and $1 \mathrm{~m} / \mathrm{s}$, respectively. The rotation of the container and airflow were necessary to avoid local over-heating of apple cubes while drying. The safe power level of microwaves
Fig. 1 Schematic diagram of vacuum-microwave dryer: 1 drying chamber, 2 fan, 3 air pipe, 4 vacuum sensor, 5 electric engine, 6 chain transmission, 7 magnetrons, 8 valve, 9 vacuum gauge, 10 vacuum pump, 11 compensation reservoir

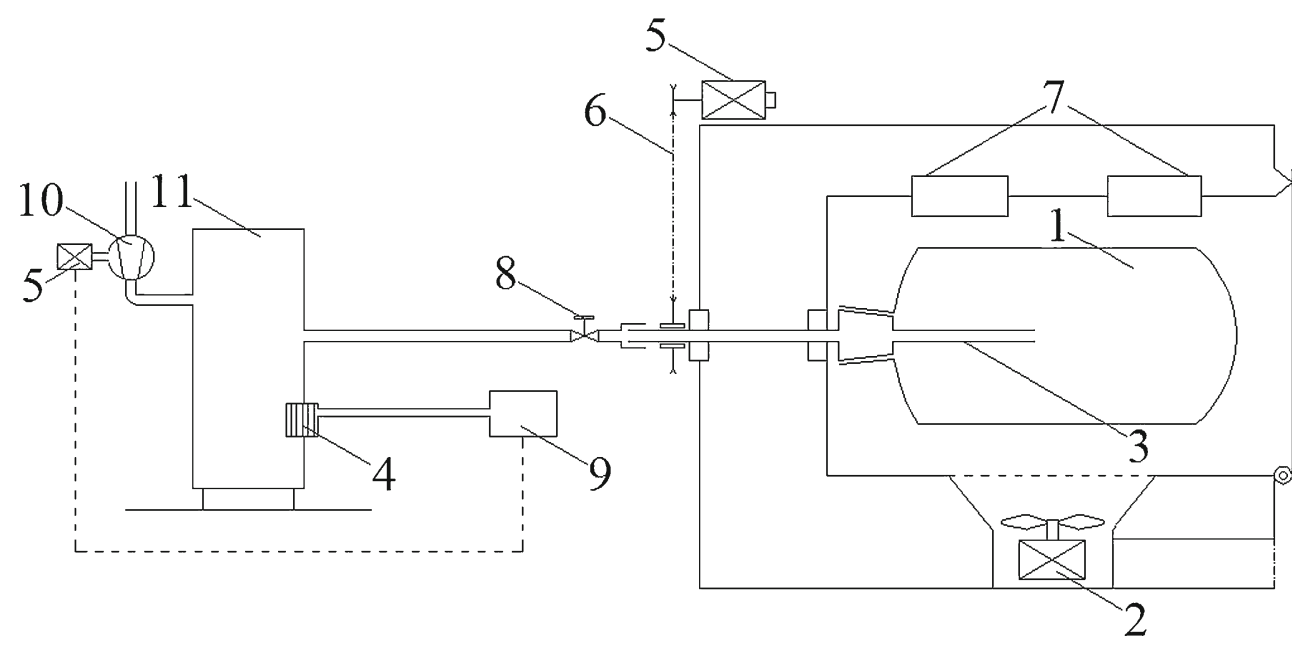


was $240 \mathrm{~W}$. It is noteworthy that exceeding the safe microwave power levels resulted in burning of the apple cubes. The experiment was interrupted whenever the mass of dried cubes was measured (Figiel 2010).

\section{Intermittent Hot Air-Dehumidified Air Drying (CTP and STP)}

The intermittent hot air-dehumidified air dryer (The University of Nottingham, Selangor, Malaysia) consists of two drying chambers with dimension of $33 \times 102 \times$ $31 \mathrm{~cm}$. A schematic diagram of the dryer is shown in Fig. 2. A heat pump is mounted on the dryer and it has a power supply system, a compressor, an electrical heater, an air conditioning unit, two hygrometers (HygroFlex, RS232, USA), and two anemometer probes Hygrolog (Rotronic, D5-U-2, USA). Hot air and dehumidified air are drying medium that exchange heat from the refrigerant of the heat pump system, which can be channeled alternately into the desired chambers. In addition, an external heater is installed as a temperature control for the dryer. The duration to swap the hot air and dehumidified is adjustable.

The dryer allows tempering period where dehumidified air is supplied to be conducted at temperature as low as
$11.54 \pm 0.26{ }^{\circ} \mathrm{C}$. It can also be classified as intermittent dryer. For instance, dehumidified air tempering period can be sandwiched between two hot air drying periods, which is called cyclic temperature profile. Besides, stepup temperature profile drying can also be performed by using this dryer, where the dehumidified air tempering period is applied at the initial stage of drying followed by hot air. Fruits cubes were weighted at 30 min interval for the first hour of drying and followed by hourly interval until the equilibrium moisture content was achieved. The air velocity was maintained at $1.4 \mathrm{~m} / \mathrm{s}$ during drying regardless of the processing period and air temperature.

\section{Heat Pump Drying}

Figure 3 shows a schematic diagram of a heat pump dryer. Apple cubes were placed on a tray with mesh size of $0.5 \times 0.5 \mathrm{~cm}$ in the middle of the drying chamber. Low temperature dehumified air was flowing horizontally at a velocity of $4 \mathrm{~m} / \mathrm{s}$ through the drying chamber during drying process. The processing air temperature and relative humidity were $35{ }^{\circ} \mathrm{C}$ and $20 \%$, respectively. Fruit cubes were weighted at $30 \mathrm{~min}$ interval for the first hour of drying and followed by
Fig. 2 Schematic diagram of intermittent hot airdehumidified air dryer

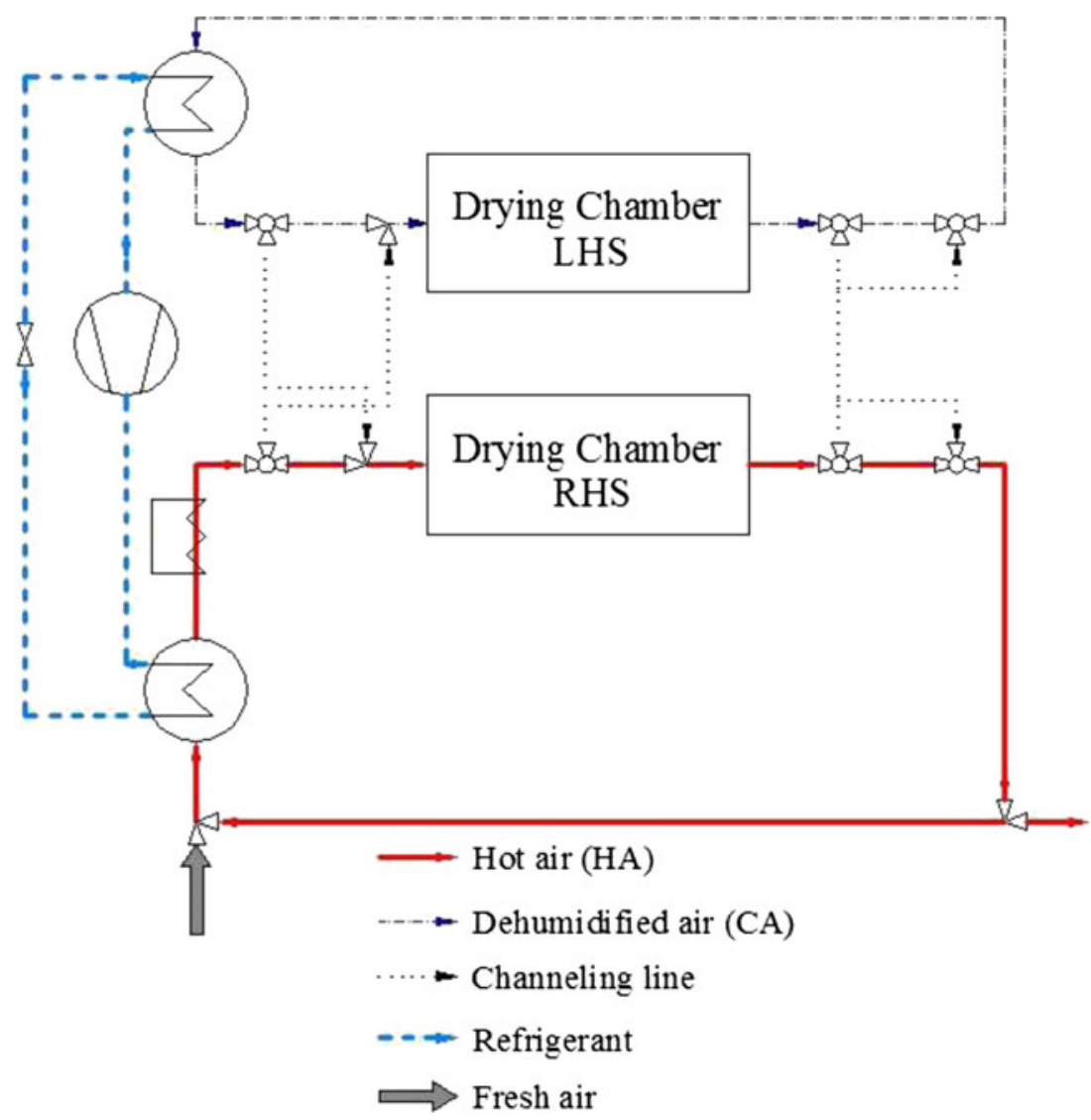




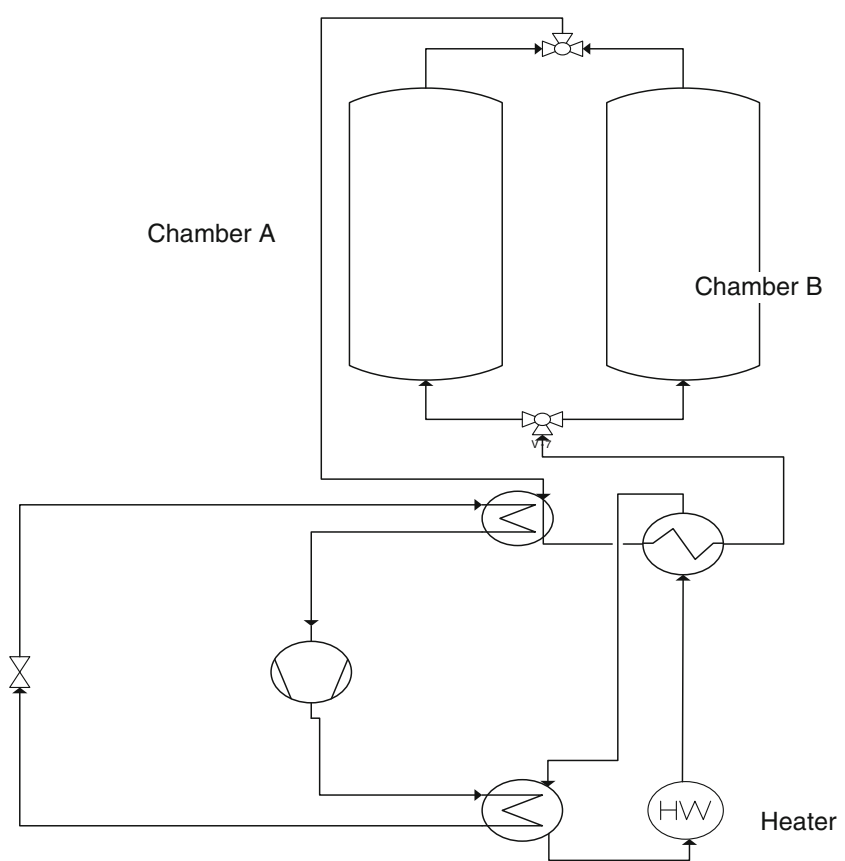

Fig. 3 Schematic diagram of a heat pump dryer

hourly interval until the equilibrium moisture content achieved.

\section{Drying Models}

The moisture ratio $M_{R}$ was determined from the Eq. 1:

$M_{R}=\frac{M(t)-M_{e}}{M_{0}-M_{e}}$

where $M(t)$ denotes moisture content after drying time $t, M_{e}$ stands for equilibrium moisture content, and $M_{0}$ is initial moisture content. The equilibrium moisture content $M_{e}$ was determined at the final stage of drying as an asymptotic value of the function fit to the experimental points using Table Curve 2D Windows v2.03.

Drying kinetics may consist of distinctive drying periods depending on the method applied in the drying process. In this work, linear falling rate period was fitted with a linear Eq. 2 and non-linear falling rate period was fitted with either one term exponential Eq. 3 or two-term exponential Eq. 4:

$M_{R}=a-b \cdot t$

$M_{R}=a \cdot e^{-k \cdot t}$

$M_{R}=a \cdot e^{-k^{\prime} \cdot t}+b \cdot e^{-k \cdot t}$
The values of effective diffusion, $D_{\text {eff }}$ for drying of apple cubes were determined at the falling rate periods of drying from the Eq. 5:

$D_{\text {eff }}=\frac{k \cdot L^{2}}{3 \pi^{2}}$

where:

$D_{\text {eff }} \quad$ Effective diffusion coefficient $\left(\mathrm{m}^{2} \min ^{-1}\right)$

$L \quad$ Size of cube sample (m)

$K \quad$ Drying constant $\left(\mathrm{min}^{-1}\right)$

Texture Profile Analysis

According to Szczesniak (2002), texture is a sensory property. Thus, sensory acceptability which refers to texture can be determined using a mechanical test such as texture profile analysis. Apple cubes were placed horizontally on the texture analyzer platform. The pretest, test, and post-test speeds were 1.0, 5.0, and $5.0 \mathrm{~mm} / \mathrm{s}$, respectively. A cylindrical probe with diameter $75 \mathrm{~mm}$ was used for texture analysis of apple cubes. During the analysis, the probe was compressed up to $50 \%$ of the original height of the samples with trigger force of $5.0 \mathrm{~g}$. Two-compression cycle were used in this texture analysis to quantified the mechanical parameters from the force-time curve (Fig. 4). The sensory attributes are defined in Eqs. 6, 7, 8, and 9.

Hardness, $H=F_{1}$

Hardness is the maximum force measured during the first compression.

Springiness, $S=\frac{T_{2}}{T_{1}}$

Springiness is the ratio of time from the start of the second area up to the second probe reversal over time

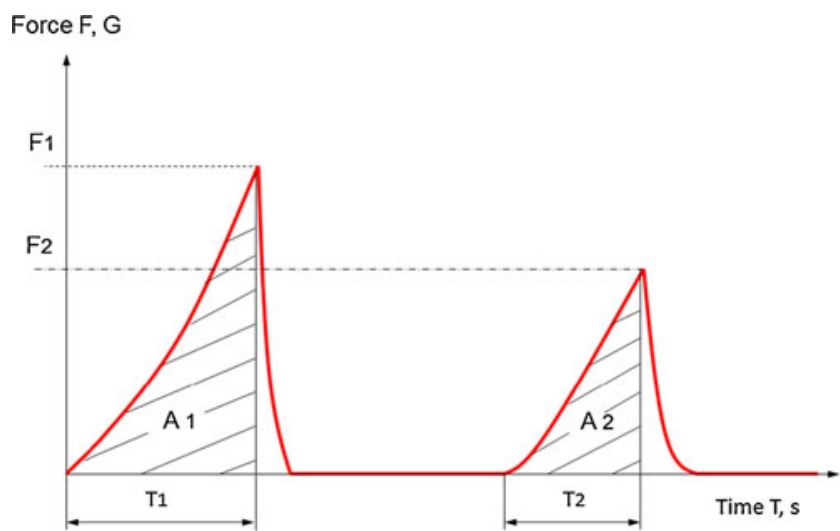

Fig. 4 Force-time curve. Abbreviations in text 
between the start of the first area and the first probe reversal.

Cohesiveness, $C=\frac{A_{2}}{A_{1}}$

Cohesiveness is the ratio of area 2 (A2)/area 1 (A1) which shows how well a sample withstands the second deformation.

Chewiness, $C W=H \times C \times S$

Chewiness is the product of hardness, cohesiveness, and springiness.

The sensory attributes mentioned above were automatically computed using texture analyzer software, Macro (Texture Exponent 32 Stable Micro System, Texture Profile Analysis, 2007).

\section{Extraction of Polyphenol Compounds}

Grounded dried apple $(1 \mathrm{~g})$ were weighed and placed in a test tube. A total of $10 \mathrm{ml}$ of $80 \%$ aqueous methanol with $1 \%$ of HCL was added and the suspension was stirred gently. The tubes were sonicated twice for $15 \mathrm{~min}$ and left for $24 \mathrm{~h}$ at $4{ }^{\circ} \mathrm{C}$. Then, the extract was centrifuged for $10 \mathrm{~min}$ at $15,000 \mathrm{rpm}$ and thereafter the supernatants were collected.

\section{Color Measurement}

The color of apple cubes was determined using an A5 Chroma-Meter (Minolta CR300, Osaka, Japan) referring to color space CIE $L^{*} a^{*} b^{*}$. The color coordinates of the samples were determined using Illuminant D65 and $10^{\circ}$ observer angle, and samples were measured against a white ceramic reference plate $\left(L^{*}=93.80 ; a^{*}=31.58 ; b^{*}=33,23\right)$. Data were mean of seven measurements.

\section{Total Polyphenol Content Analysis}

Total polyphenol content was measured using FolinCiocalteu colorimetric method described previously by Gao et al. (2000). Apple cubes extracts $(0.1 \mathrm{~mL})$ were mixed with $0.2 \mathrm{ml}$ of Folin-Ciocalteu reagent and $2 \mathrm{ml}$ of $\mathrm{H}_{2} \mathrm{O}$. Then, the mixture was incubated at room temperature for $3 \mathrm{~min}$ and $1 \mathrm{ml}$ of $20 \%$ sodium carbonate was added to the mixture. Analysis of total polyphenols was determined after $1 \mathrm{~h}$ of incubation at room temperature. The absorbance of the resulting blue color was measured at $765 \mathrm{~nm}$ using an UV-vis spectrophotometer (Shimadzu, UV-2401 PC; Kyoto, Japan). Quantification was done with respect to the standard curve of gallic acid. The results were expressed as gallic acid equivalents (GAE), milligrams per $100 \mathrm{~g}$ of dry mass. All analysis was performed in triplicates $(n=3)$.
Antioxidant Activity

The DPPH radical scavenging activity was determined using the method proposed by Yen et al. (1995). The DPPH $(100 \mathrm{mM})$ was dissolved in pure ethanol $(96 \%)$. Then, the $1.0 \mathrm{ml}$ of DPPH solution was added to $1 \mathrm{ml}$ of polyphenol extracts with $3.0 \mathrm{ml}$ of ethanol. The mixture was shaken vigorously and placed in a dark room for $10 \mathrm{~min}$. The decrease in absorbance of the resulting solution was measured at $517 \mathrm{~nm}$. The results were corrected for dilution and expressed in millimolars of Trolox per $100 \mathrm{~g}$ dry mass. All determinations were performed in triplicates $(n=3)$.

\section{Statistical Analysis}

Results were reported as mean values \pm standard error (SE). Analysis of variance was performed by using SAS statistical package (SAS Institute Inc, SAS/STAT 9.1, 2004). Mean were compared by using Tukey's Studentized Range (HSD) test at confidence level of $95 \%$, where $p<0.05$ represent a significant difference. Statistical parameters such as determination coefficient $R^{2}$ and root mean square error (RMSE) were used to evaluate the goodness of fit.

\section{Results and Discussion}

Comparison of Drying Methods

Figure 5 shows the drying curves of apple cubes dried by various methods applied in this study. The mathematical description of these curves with respect to the drying periods can be found in Table 2. Heat pump vacuum-microwave (HP/VM) drying kinetics study is excluded because of the extremely short duration of VM finish drying, which cannot be shown clearly in this figure. Figure 5 revels that the drying curves of single-stage drying such as convective drying (C) and continuous heat pump drying (HP) are typically given by an exponential function. Whereas intermittent drying such as intermittent hot air-dehumidified air drying as well as varying temperature profile such as stepup temperature profile gave non-conventional drying curves. This is due to the fact that the change in drying temperature resulted in the change in humidity potential between the moisture content in the drying material and the humidity in the drying medium. Figure 5 clearly shows that the moisture ratio reduction of CTP and STP exhibits two totally different paths. The gradient of the drying curves indicates the drying rate.

The drying rate is plotted versus the moisture ratio in Fig. 6. For one stage drying such as convective hot air drying (C) and continuous heat pump drying (HP), the drying rate curves are rather smooth which consist of a short 
Fig. 5 Drying kinetics of apple by the convective $(C)$, vacuum microwave $(V M)$, cyclic temperature profile $(C T P)$, stepup temperature profile $(S T P)$, and heat pump $(H P)$ dryers

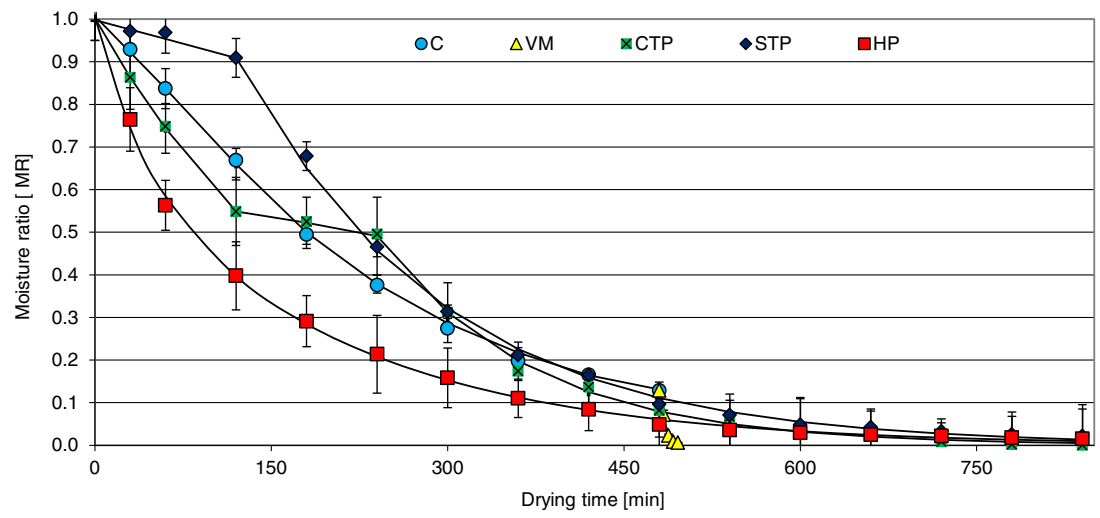

period of initial transient followed by falling rate period. On the other for varying temperature profile such as intermittent hot air-dehumidified air drying and step-up temperature profile, the drying rate curves consist of various distinctive drying periods, namely initial transient and two or more falling rate periods occurred when different drying temperature profiles were applied. Whereas for the two-stage heat pump drying cum vacuum microwave drying, the drying rate curve exhibits a significant rise in drying rate when vacuum microwave drying was applied in the second stage. The existence of initial transient period, increasing rate period, and multiple distinctive falling rate periods of the various drying techniques applied in this study can be clearly seen from Fig. 6.

\section{Convective Vacuum-Microwave Drying}

An obvious inflection point can be clearly seen from the C/VM drying curve representing two drying stages (Fig. 5). An extremely high drying rate can be seen from Fig. 6 at the final stage of VM drying. A great increment of drying rates during VM drying was because of rapid removal of water from the internal structure of apple cubes by the microwave energy.

In vacuum-microwave drying, the difference in moisture content between the external and internal parts of fruit cube is lower since water diffusion and temperature gradients are corresponded. This is because of internal heating is provided by microwaves. In combined $\mathrm{C} / \mathrm{VM}$ method convective predrying is necessary to remove large amount of water at satisfied drying rate at the first drying period. In addition, convective air drying creates non-uniform distribution of moisture inside the sample. An external layer composed of well-dried cells encompasses internal part which has higher moisture content. During vacuum-microwave drying, the energy of microwaves is absorbed by water in the internal part of pre-dried cube. This creates a relatively large vapor pressure in the internal of the material, allowing rapid transfer of moisture to the surrounding vacuum and preventing structural collapse. This process, well-known as the microwave puffing phenomenon, creates a porous texture of the food. Further, it reduces the density of the material (Sham et al. 2001). Hence, the dried samples become hard and crispy.

\section{Heat Pump Drying}

Figure 6 shows that the drying rate determined for apple cubes dehydrated by heat pump drying decreased with decreasing of moisture content. The drying rates of fruits subjected to HP drying are higher at the initial stage of drying compared to the other drying methods. This is because of the low relative humidity. During HP drying, the chamber temperature and relative humidity was as low as $36{ }^{\circ} \mathrm{C}$ and $18 \%$, respectively. According to Pal et al. (2008) relative humidity is the prominent factor during initial stage of drying because of high moisture gradient between the surface and environment. In addition, the air velocity is another factor that affects the drying rate. The air velocity during drying was as high as $4 \mathrm{~m} / \mathrm{s}$.

Intermittent Hot Air-Dehumidified Air Cyclic Temperature and Step-Up Temperature Drying

At the initial stage of hot air-dehumidified air step-up temperature drying, drying rate of apple cubes was very low because of the dehumidified air supplied to the samples. The dehumidified air temperature and relative humidity were about $10{ }^{\circ} \mathrm{C}$ and $68 \%$, respectively. When hot air was supplied to the drying chamber, the drying rate increased significantly (Fig. 6). It is hypothesized that during dehumidified air tempering period, fruits cell's structure shrunk. When hot air is charged to chambers, the cell structure of fruits inside the chambers expands. For fruits undergone intermittent hot air-dehumidified air cyclic temperature drying (CTP), a minimum point can be seen from the drying rate versus moisture content curve. The decreasing of drying rate at this point was caused by the effect of dehumidified air drying between the two hot air drying periods. 
Comparison of Overall Drying Duration and Moisture Content of Dried Product

Figure 5 shows the decrease of moisture ratio, MR with drying time, $t$ for the C/VM, CTP, STP, and HP drying methods. Drying of apple cubes by $\mathrm{C} / \mathrm{VM}$ method required shorter drying duration compared to the other drying methods. The total drying time of this method was about $490 \mathrm{~min}$. The drying time was shorter due to the application of vacuum microwave drying at the final stage which reduced the moisture content appreciably. In addition, large vapor pressure gradient between the samples interior and surface created an internal moisture vibration. After predrying by convective hot air, about $13 \%$ of moisture remained in the core of the samples. According to Kaensup et al. (2002), during VM drying, moisture at the inner part of the samples would be removed rapidly with increasing vapor pressure.

It was found that the final moisture contents of samples dried by C/VM, CTP, STP, HP, and HP/VM methods were $0.051,0.069,0.065,0.121$, and $0.029 \mathrm{~g} \mathrm{H}_{2} \mathrm{O} / \mathrm{g} \mathrm{dm}$, respectively. It can be seen that the final moisture content is correlated to the drying temperature in the final stage.

\section{Parameter Models}

\section{Convective Vacuum Microwave Drying}

As mentioned earlier, convective vacuum-microwave drying consisted of two stages. The first stage was convective pre-drying (C) while the second one was vacuummicrowave (VM) finish drying. The first stage can be divided into two drying periods. The drying kinetics of the first drying period (I) is fitted well with a linear Eq. 2 whereas the second drying period (II) with the two-term exponential Eq. 3. Equation 3 also fits well for the drying in the second stage. It means that first falling rate period and second falling rate period were exhibited respectively during drying periods II and III (Table 2).

Coefficient $a$ in Eq. 2 is the initial value of moisture ratio during drying. The $b$ value is the constant drying rate at the first drying period calculated by differentiation of Eq. 2 with reference to time, $t$. It is obvious that the higher $b$ value the higher decrease in moisture ratio per time (minutes).

Coefficient $a$ in Eq. 3 can be regarded as critical moisture ratio, $M R_{c r}$ that distinguishes the two distinctive falling rate periods. The higher the $k$ value, the higher decrease in moisture ratio per time (minutes) is observed. The $k$ value during drying periods II and III was $4.63 \times 10^{-3}$ and $188.15 \times 10^{-3} \mathrm{~min}^{-1}$, respectively (Table 2). It is clearly seen that vacuum-microwave drying in III period was much rapid than convective drying in II period. 
Fig. 6 Drying rate versus moisture content for apple undergone convective $(C)$, vacuum microwave $(V M)$, cyclic temperature profile $(C T P)$, step-up temperature profile $(S T P)$ and heat pump $(H P)$ drying

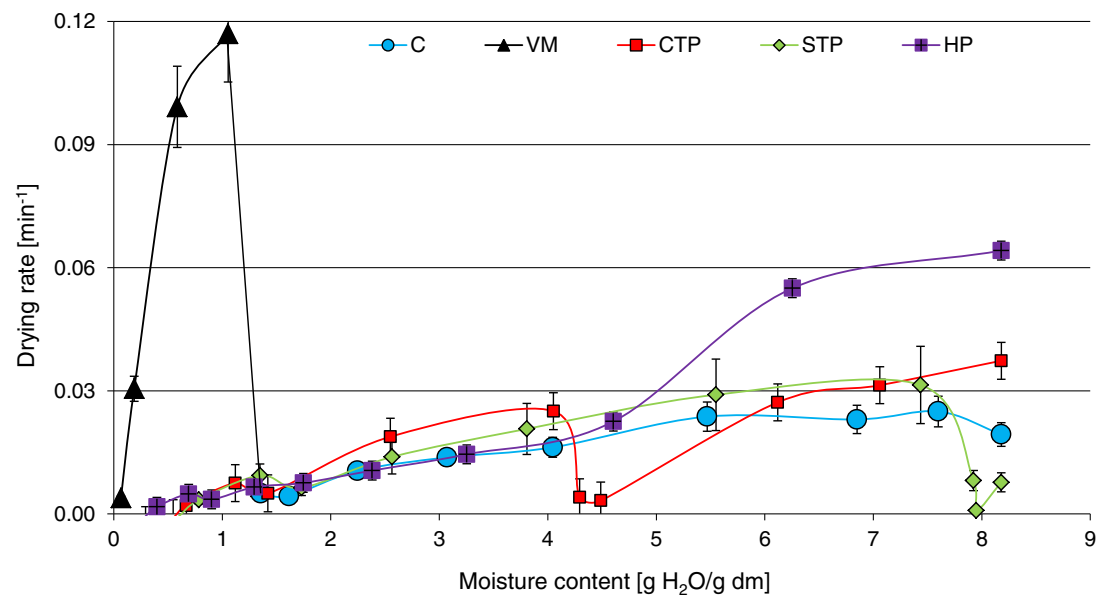

\section{Cyclic Temperature Profile Drying}

The CTP drying kinetics has three drying periods. The first and third falling rate periods can be fitted into Eq. 3, while the second constant drying rate period by Eq. 2. Parameter $b$ obtained for the linear model as shown in Table 2 was $4.44 \times$ $10^{-4}$. This small value indicates that the drying rate was extremely slow. The purpose of applied dehumidified air in the drying process is to reduce the surface temperature to avoid case hardening effect. The pore and cell structure of the samples could be retained throughout the dehumidified air tempering period. More moisture could diffuse to the sample surface for evaporation in the subsequent hot air drying. As the result the value of drying constant $k$ determined for the third drying period was relatively high $(7.60 \times$ $10^{-3} \mathrm{~min}^{-1}$ ) and even exceeded the corresponding value obtained for the first drying period $\left(k=4.97 \times 10^{-3} \mathrm{~min}^{-1}\right)$. It was mentioned earlier that the values of parameter $a$ equaled the moisture ratios dividing the characteristic drying periods in convective vacuum microwave drying. In this case $a$ value indicates initial moisture ratio for the dehumidified air period. During dehumidified air tempering period, moisture reduction was very low, and amounted to about $13 \%$.

\section{Step-Up Temperature Profile Drying}

Intermittent hot air-dehumidified air step-up temperature profile drying consisted of two drying period: linear (I) and exponential (II). At the initial stage of drying, dehumidified air was channeled to the chamber with fruit. Moisture evaporated from the samples at this stage was about $10 \%$ of the initial moisture content based on the $a$ values shown in Table 2. Dehumidified air tempering allows internal moisture diffuse to the samples surface while maintaining the surface temperature at low level. When hot air applied to the samples, bulk moisture at the sample surface was removed through evaporation.
Heat Pump Drying

The drying equation used to model the drying kinetics of apple cubes under heat pump was a two-term exponential model (4). This model consists of four parameters: $a, b, k^{\prime}$, and $k$ (Table 2). At the very beginning of drying, at $t=0$, Eqs. 1 and 4 can be simplified respectively to Eqs. 10 and 11:

$M_{R_{(t=0)}}=\frac{M_{0}-M_{e}}{M_{0}-M_{e}}=1$

$M_{R_{(t=0)}}=a+b$

Eventually, the sum of $a$ and $b$ values are equal to 1 (Eq. 12),

$a+b=1$

Parameters $k^{\prime}$ and $k$ are drying constants in Eq. 4. These drying constants refer to exponential terms associated with parameters $a$ and $b$, respectively. The decreasing in time of those exponential terms is dependent on drying constants. Relatively high value of drying constant $k^{\prime}(25.26 \times$ $\left.10^{-3} \mathrm{~min}^{-1}\right)$, when compared with time constant $k(5.91 \times$ $\left.10^{-3} \mathrm{~min}^{-1}\right)$, indicates that the exponential term associated with parameter $a$ is decreasing very fast. Moreover, the value of parameter $a(0.2992)$ was much lower than value of parameter $b(0.7051)$. Therefore parameter $k$ could be selected as drying constant for effective diffusivity determination (Eq. 5).

\section{Effective Diffusivity Values}

Table 2 shows the values of effective diffusivity $D_{\text {eff. For }}$ linear model, the drying rate is constant and the governing mechanism is evaporation. Therefore, diffusivity is not applicable. Diffusivity is obtained from falling rate period where diffusion is the governing mechanism. Depending on the type of drying methods, different methods will have 
different type of falling rate period, thus results in different transport properties. Therefore, for apple cubes undergone convective vacuum-microwave $(\mathrm{C} / \mathrm{VM})$ and intermittent hot air-dehumidified air cyclic temperature drying (CTP) two values of $D_{\text {eff }}$ were found due to the existence of two different falling rate drying periods. Referring to Table 2, the effective diffusivity of apple cubes dried by using convective drying was $3.522 \times 10^{-8} \mathrm{~m}^{2} / \mathrm{min}$. In this study, vacuum-microwave drying was applied after convective drying. The apple cubes moisture content was about $1.05 \mathrm{~g} \mathrm{H}_{2} \mathrm{O} / \mathrm{g} \mathrm{dm}$ after pre-drying. It is noteworthy that the drying rate increased significantly with the application of VM drying. The effective diffusivity value also increased significantly during the VM drying reaching $1.431 \times$ $10^{-6} \mathrm{~m}^{2} / \mathrm{min}$.

Effective diffusivity of apple cubes dried using intermittent hot air-dehumidified air cyclic temperature drying method (CTP) increased after the tempering period from $3.781 \times 10^{-8}$ to $5.780 \times 10^{-8} \mathrm{~m}^{2} / \mathrm{min}$ due to the same reasons, which increased the value of drying constant $k$. On the other hand, the value of effective diffusivity for apple cubes dried by intermittent hot air-dehumidified air step-up temperature profile method had an intermediate value of $4.477 \times$ $10^{-8} \mathrm{~m}^{2} / \mathrm{min}$.

The effective diffusivity of apple cubes dried by heat pump method was calculated basing on the drying constant $k^{\prime}$. The value of $D_{\text {eff }}$ amounting to $3.879 \times 10^{-8} \mathrm{~m}^{2} / \mathrm{min}$ was similar to that obtained for convective pre-drying and much lower compared to other drying methods. This can be explained by the low drying rate values obtained from the final period of drying. The fact is that at the beginning of dehydration the drying rate for heat pump method was the highest because of the relatively high value of $k^{\prime}$. However, the value $k$ in that model is much lower, which is being responsible for the low drying rate.

\section{Product Quality}

\section{Textural Attributes}

The values of hardness of apple cubes dried by different methods are shown in Fig. 7. Hardness is the force required to attain a given deformation when the fruits are compressed or poked. It is noticeable that the hardness of apple cubes finish-dried using VM finish drying is significantly higher than that obtained for the samples dehydrated by other methods $(p<0.05)$. The force required compressing the apple cube until $50 \%$ of its height was about 8,000 and 6,500 $\mathrm{G}$ for (HP/VM) and (C/VM) dried samples, respectively. The increase of hardness could be because the rapid mass transfer that damaged the membrane and cell structure of the fruits during the final stage VM drying. According to

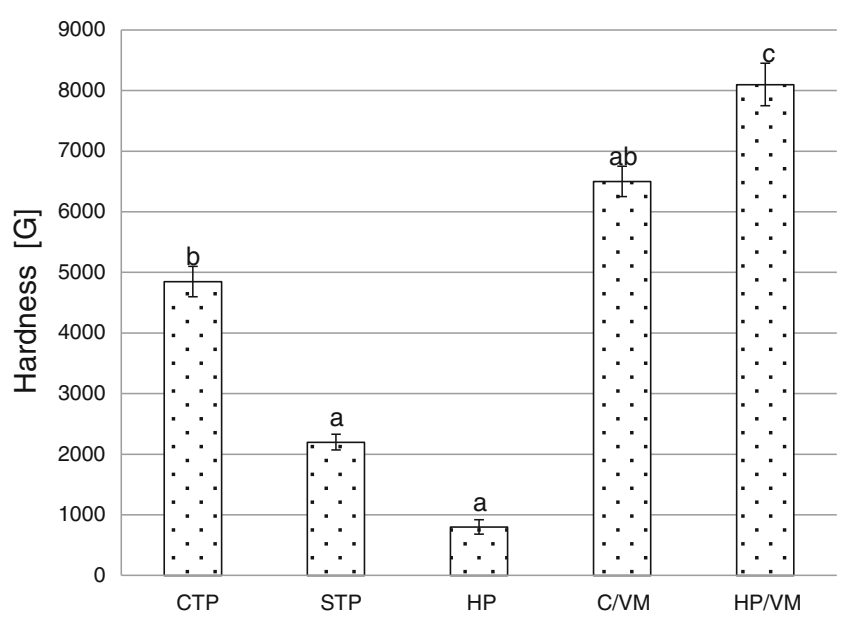

Fig. 7 Hardness of apple cubes undergone cyclic temperature profile $(C T P)$, step-up temperature profile $(S T P)$, heat pump $(H P)$, convective vacuum-microwave $(C / V M)$, and heat pump vacuum-microwave $(H P /$ $V M)$ drying process. Different lower or upper case letters $(a, b, c \ldots)$ denote significant differences $(p<0.05)$ between variety, $n=3$

Brown et al. (2008), mass transport of microwave drying may damage the product structure in the form of "puffing". Thus, the damage cell structure becomes hard. Another important factor responsible for the increase of hardness of VM finish-dried samples is the low final moisture content when compared with other samples. VM drying method enables samples to reach low moisture content at relatively short duration and therefore the product with harder texture was obtained. This method is preferred to process dried products which have harder and crispy texture such as some snack food (Szczesniak 2002).

The hardness of STP apple cubes is $50 \%$ lower than hardness of CTP samples. However, the lowest hardness (ca $730 \mathrm{G}$ ) is found in HP samples. According to Khin et al. (2007), the turgor pressure determines hardness of apple tissue. Thus, the texture of apple is significantly affected by the cell structure arrangement and final water content when different drying methods are used. Dehumidified air applied to the sample in the middle (CTP) or at the beginning (STP) of drying can maintain the cell structure of the samples and at the same time allows the transport of internal moisture to the samples surface. Thus, the hardness of CTP and STP samples without significant structural damage is lower compared with dried samples finally dried by VM drying.

Based on the results reveal in the Fig. 7, HP is the most suitable drying method for producing soft dried fruits. This is due to the temperature and relative humidity that do not cause cell structure damage. Usually, food product with soft texture is more demanded by most of the consumers than product characterized by hard texture (Szczesniak and Kahn 1971).

The chewiness of apple cubes undergone different drying methods is shown in Fig. 8. Chewiness is another textural attribute, which is defined as the energy that is required in 
Fig. 8 Chewiness of apple cubes undergone cyclic temperature profile $(C T P)$, stepup temperature profile $(S T P)$, heat pump $(H P)$, convective vacuum-microwave $(C / V M)$, and heat pump vacuummicrowave $(H P / V M)$ drying process. Different lower or upper case letters $(a, b, c \ldots)$ denote significant differences $(p<0.05)$ between variety, $n=3$

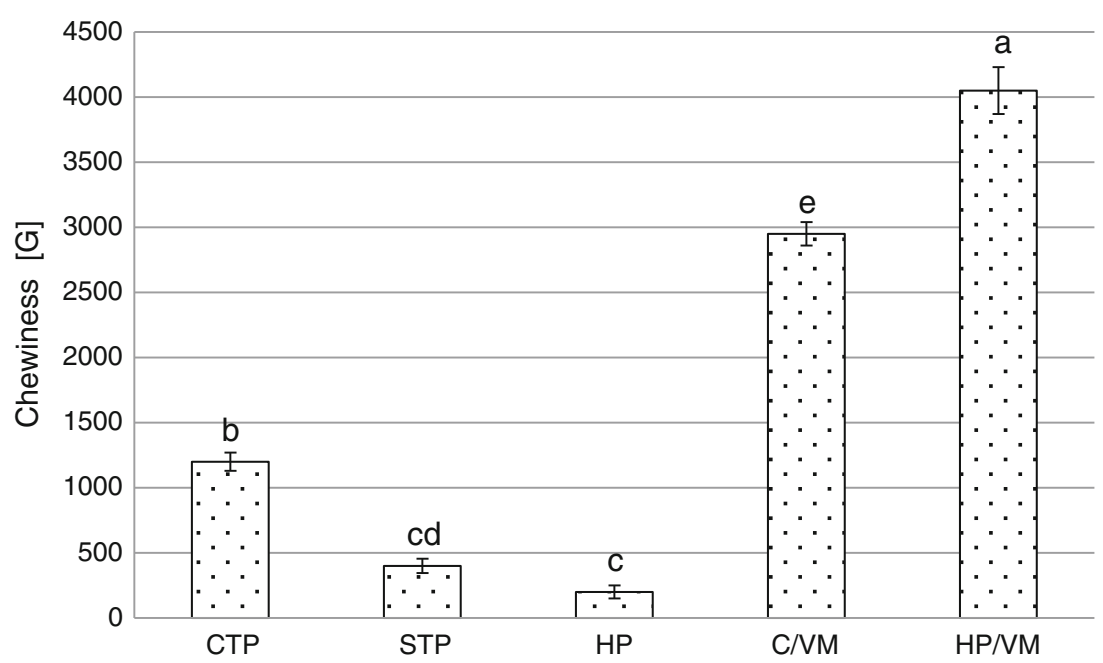

masticating a solid food at a state ready before swallowing. Chewiness is the product of hardness, cohesiveness, and springiness (Eq. 9). This study reveals that the values of chewiness (Fig. 8) reflects the values of hardness (Fig. 7). This means that the effect of cohesiveness and springiness on the profile of chewiness is negligible and different methods produced the dried product that has similar cohesiveness and springiness. Higher values of chewiness amounting to 4,000 and 3,000 $\mathrm{G}$ were obtained for apple cubes finally dried by VM drying after HP and convective pre-drying. This indicates that the length of time required masticating this samples before swallowing is longer. On the other hand, samples dried by HP method gave the lowest chewiness (200 G).

\section{Visual Attributes}

Figure 9 shows the image of fresh and dehydrated apple dried using different drying methods. The apple cubes dried by C/VM method appear darker compared to fruits dried using other drying methods. This visual observation was confirmed by the results of instrumental measurement of color (Table 3). Namely, C/VM sample obtained the lowest value of parameter $L^{*}$ amounting to $66.21 \pm 2.67 .95$. The change of color could be because of enzymatic browning and caramelization effect or due to the protein denaturation (Krokida et al. 1999) occurring during convective pre-drying and during volumetric microwave heating, which gives rise to high temperature within the dried material. On the other hand, the brightest samples were obtained from HP $\left(L^{*}=73 \pm 2.57\right)$ and HP/VM $\left(L^{*}=77.11 \pm 3.77\right)$ method, which indicate that low temperature drying provides brighter color dried product. Apple has high amount of reducing sugars. It contains $5.36 \mathrm{~g}$ fructose, $1.61 \mathrm{~g}$ glucose, $1.39 \mathrm{~g}$ sucrose, and $2.04 \mathrm{~g}$ sorbital per $100 \mathrm{~g}$ of fresh weight (Fourie et al. 1991) and 11 to $17 \mathrm{mg}$ of vitamin C per $100 \mathrm{~g}$ of fresh weight (Samotus 1988). With these amounts of reducing sugars, Maillard reaction and oxidation of ascorbic acids took place when the apples had been exposed to hot air $8 \mathrm{~h}$ at temperature of $70^{\circ} \mathrm{C}$. It has been reported that hot air drying of apple at 60 to $65^{\circ} \mathrm{C}$ in a hot air dryer for $5.5 \mathrm{~h}$ could only retain $63.7 \%$ of fresh apple vitamin C (Cui et al. 2008). The losses of ascorbic acid could be due to the oxidation of vitamin $\mathrm{C}$. The oxidation of ascorbic acid produces reactive carbonyls compounds such as a, b-unsaturated carbonyls, which are potent browning agents (Clegg et al. 1965; Flink 1983; Wedzicha 1981). These browning products are furan-type compounds, lactones, acids, 3-hydroxy-2-pyrone, furaldehyde, and 5-hydroxymethylfuraldehyde (Clegg and Morton 1965; Clegg et al. 1965; Kanner et al. 1981; Robertson et al. 1986; Tatum et al. 1969; BeMiller et al. 1996).

The intermittent hot air-dehumidified air cyclic (CTP) and step-up (STP) temperature drying methods could produce dehydrated apple cubes with attractive appearance

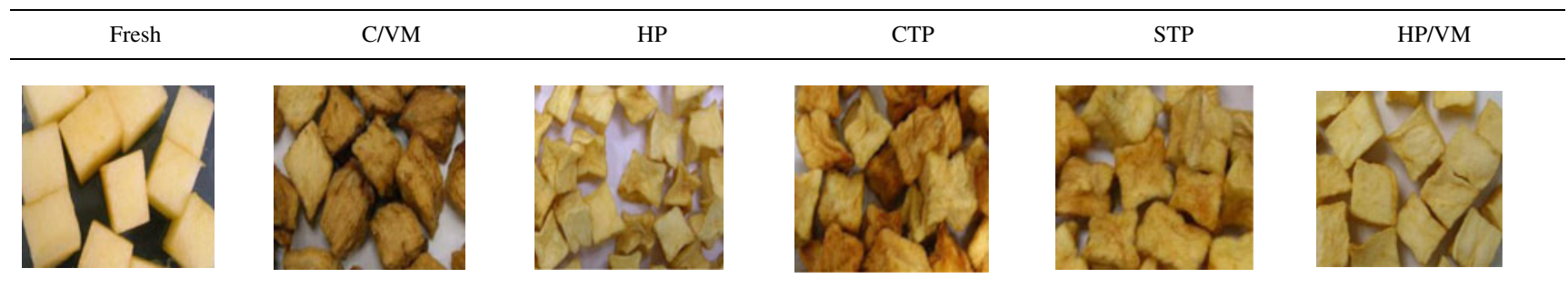

Fig. 9 Image of fresh samples, cyclic temperature profile $(C T P)$, step-up temperature profile $(S T P)$, heat pump $(H P)$, convective vacuummicrowave $(C / V M)$, and heat pump vacuum-microwave $(H P / V M)$ dried apple cubes 
Table 3 Color parameters $L^{*}, a^{*}$, and $b^{*}$ of apple samples

\begin{tabular}{llll}
\hline Sample & \multicolumn{3}{l}{ Color parameter } \\
\cline { 2 - 4 } & $L^{*}$ & $a^{*}$ & $b^{*}$ \\
\hline Fresh & $79.25 \pm 2.88 \mathrm{~d}$ & $3.43 \pm 0.47 \mathrm{c}, \mathrm{d}$ & $15.55 \pm 2.80 \mathrm{c}$ \\
C/VM & $66.21 \pm 2.67 \mathrm{a}$ & $7.57 \pm 1.55 \mathrm{a}$ & $30.98 \pm 0.87 \mathrm{~b}, \mathrm{~d}$ \\
HP & $73.00 \pm 2.57 \mathrm{~b}, \mathrm{c}$ & $1.61 \pm 0.88 \mathrm{~b}, \mathrm{c}$ & $21.90 \pm 6.21 \mathrm{a}, \mathrm{c}$ \\
CTP & $66.95 \pm 4.32 \mathrm{a}$ & $6.62 \pm 3.49 \mathrm{a}$ & $28.76 \pm 1.87 \mathrm{a}, \mathrm{b}$ \\
STP & $70.60 \pm 2.28 \mathrm{a}, \mathrm{b}$ & $5.22 \pm 2.00 \mathrm{a}$ & $35.87 \pm 2.86 \mathrm{~d}$ \\
HP/VM & $77.11 \pm 3.77 \mathrm{c}, \mathrm{d}$ & $0.05 \pm 0.57 \mathrm{~b}$ & $26.03 \pm 3.33 \mathrm{a}, \mathrm{b}$ \\
\hline
\end{tabular}

Mean values in the rows followed by the same letter are not significantly different; Tukey's multiple-range test, $p<0.05$

such as golden yellow and golden light brown colors which were confirmed by relatively high $b^{*}$ values amounting to $28.76 \pm 1.48$ and $35.87 \pm 2.86$, respectively. However, shrinkage effect is visible. The hot air drying period and uneven evaporation of surface water gives rise to this phenomenon.

\section{Total Polyphenol Content and Radical Scavenging Activity}

Figures 10 and 11 show the total polyphenol content and DPPH radical scavenging activity of apple cubes dried by using different drying methods. Referring to Figs. 10 and 11, the retention of phenolic contents and antioxidant activity after drying is closely related to the drying technique. The TPC of heat pump vacuum-microwave-dried apple cubes is $500 \mathrm{mg} \mathrm{GAE} / 100 \mathrm{~g} \mathrm{dm}$. This is about 60 to $70 \%$ higher that the retained TPC of intermittent hot air-dehumidified air drying (CTP and STP), heat pump, and convective vacuummicrowave dried apple cubes. This is because of the native procyanidins of apple, which could inhibit polyphenol oxidase (PPO) activity; however, initial drying was conducted at

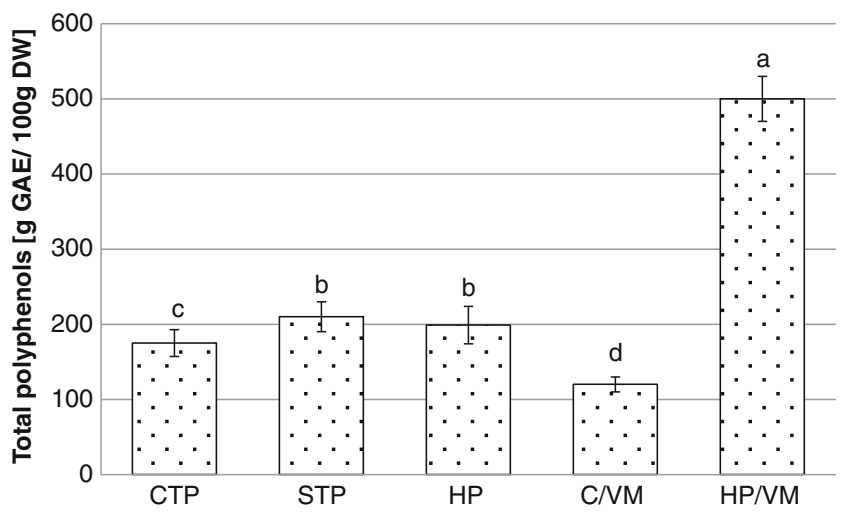

Fig. 10 Total polyphenol content of apple cubes cyclic temperature profile $(C T P)$, step-up temperature profile $(S T P)$, heat pump $(H P)$, convective vacuum-microwave $(C / V M)$, and heat pump vacuum-microwave $(H P / V M)$ drying process. Different lower or upper case letters $(a, b, c \ldots)$ denote significant differences $(p<0.05)$ between variety, $n=3$

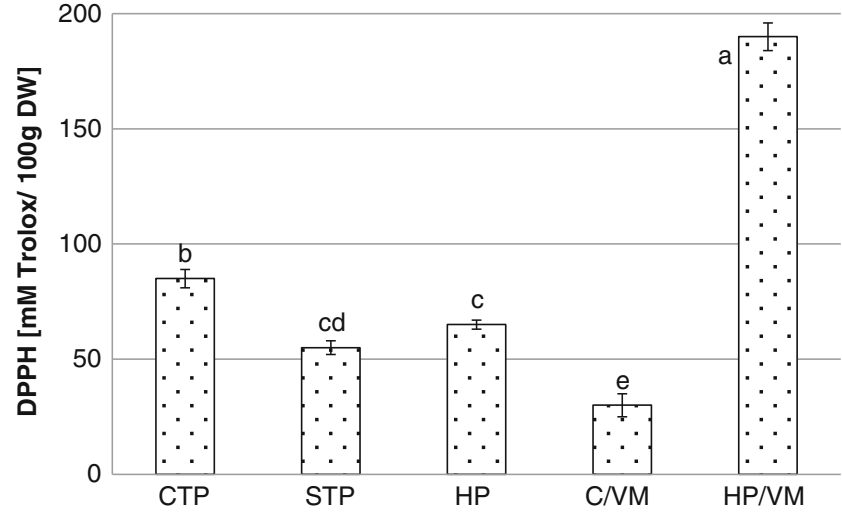

Fig. 11 DPPH radical scavenging activity of apple cubes undergone cyclic temperature profile $(C T P)$, step-up temperature profile $(S T P)$, heat pump $(H P)$, convective vacuum-microwave $(C / V M)$, and heat pump vacuum-microwave $(H P / V M)$ drying process. Different lower or upper case letters $(a, b, c \ldots)$ denote significant differences $(p<0.05)$ between variety, $n=3$

low drying temperature. Procyanidins were the most abundant polyphenol in apple followed by hydroxycinnamic acids, dihydrochalcones, flavonols, anthocyanins, and flavan-3-ols (Heras-Ramírez et al. 2012; Oleszek et al. 1988; Guyot et al. 1998; Sanoner et al. 1999; Tsao et al. 2003; Alonso-Salces et al. 2004). The inhibitory effect of oxidized procyanidins was twice that of native procyanidins of apple (Le Bourvellec et al. 2004). Oxidation products of caffeoylquinic acid and (-)epicatechin also could inhibit the PPO activity of apple.

The retained TPC of C/VM dried apple is the lowest, which is about $120 \mathrm{mg}$ GAE $/ 100 \mathrm{~g} \mathrm{dm}$. This could be because of decomposition and depolymerization of total polyphenol content compounds of apple. Depolymerization of procyanidins may occur at higher temperature. According to Hamauzu et al. (2007), Chinese quince phenolic (mostly procyanidins) solution subjected to heat treatment changed from almost colorless, pale yellow, to a reddish color due to denaturation of procyanidins. Zheng et al. (2009) also found that reaction temperature higher than $50{ }^{\circ} \mathrm{C}$ inhibited enzyme activity and decreased the total polyphenol content of apple. The enzymatic activity was significant during the convective air drying. According to Yen and Huang (2000), heating process will degrade the TPC, where the TPC of Hsian-Tao extract decreased about $50 \%$ because of additional $3 \mathrm{~h}$ of continuous heating. Intermittent hot air-dehumidified air drying (CTP) also can retain higher amounts of TPC values compared to $\mathrm{C} / \mathrm{VM}$ drying. However, it is not significantly different compared to retained TPC values of HP dried apple cubes. The average retained TPC is about $200 \mathrm{mg} \mathrm{GAE} / 100 \mathrm{~g} \mathrm{dm}$. This is due to the application of dehumidified air at the beginning or in the middle of the drying process, which interrupted the continuous hot air drying period. According to Lim et al. (2007), heating treatments would deactivate enzymatic activity and degrade the phenolic content. 
Similarly, the DPPH radical scavenging activities of apple cubes dried under HP/VM was the highest compared to the other drying methods, which is almost $200 \mu \mathrm{M}$ Trolox/100 g dm followed by intermittent hot airdehumidified air drying (CTP and STP), heat pump, and convective vacuum-microwave dried apple cubes, which gave about $800,50,50$, and 25 , respectively.

Comparing Figs. 10 and 11, TPC correlates with DPPH. This is because the lower the amount of total polyphenol content, the lower the antioxidant activity values (Dueñas et al. 2007).

\section{Conclusions}

Overall drying time for convective vacuum microwave dried apple was $490 \mathrm{~min}$, which is about $50 \%$ shorter than other drying methods tested in this study. This was because the effective diffusivity values for convective and VM methods were $3.52 \times 10^{-8}$ and $1.43 \times 10^{-6} \mathrm{~m}^{2} / \mathrm{min}$, respectively while for samples undergone heat pump or intermittent hot air dehumidified air cyclic (CTP) and step-up temperature (STP) drying methods these values varied from $3.781 \times 10^{-8}$ to $5.78 \times$ $10^{-8} \mathrm{~m}^{2} / \mathrm{min}$. The profile of drying kinetics of apple cubes dehydrated by different methods was divided into three drying periods. These periods were divided by the critical moisture contents incorporated to the drying models. The overall product quality analysis showed that combined HP/VM drying method gave the best product in terms of physical appearance, antioxidant activity, and total polyphenol content. The shortest drying time was ensured by early application of VM finish drying while the softest texture was found for HP dried apple cubes.

All proposed methods of drying could be used in commercial scale for modification of texture attributes according to potential consumer preferences. However, heat pump vacuum-microwave method is the best drying technique to produce crispy and healthy apple snack of nice appearance.

Acknowledgment The authors wish to acknowledge the support given by The Ministry of Science and Technology and Innovation, Malaysia through e-Science funding (03-02-12-SF0001) and The Polish Ministry of Science and High Education Project (N312 031 32/2036).

Open AccessThis article is distributed under the terms of the Creative Commons Attribution License which permits any use, distribution, and reproduction in any medium, provided the original author(s) and the source are credited.

\section{References}

Aktaş, M., Ceylan, İ., \& Yilmaz, S. (2009). Determination of drying characteristics of apples in a heat pump and solar dryer. Desalination, 239, 266-275.
Alonso-Salces, R. M., Barranco, A., Abad, B., Berrueta, L. A., Gallo, B., \& Vicente, F. (2004). Polyphenolic profiles of basque cider apples cultivars and their technological properties. Journal of Agricultural and Food Chemistry, 52, 2938-2952.

BeMiller, J. N., \& Whistler, R. L. (1996). Carbohydrate. In O. R. Fennema (Ed.), Food chemistry (3rd ed., p. 157). New York: Marcel Dekker, Inc.

Brown, Z. K., Fryer, P. J., Norton, I. T., Bakalis, S., \& Bridson, R. H. (2008). Drying of foods using supercritical carbon dioxide - investigation with carrot. Innovative Food Science and Emerging Technologies, 9, 280-289.

Chua, K. J., Mujumdar, A. S., Chou, S. K., Hawlader, M. N. A., \& Ho, J. C. (2000). Convective drying of banana, guava and potato pieces: effects of cyclical variations of air temperature on convective drying kinetics and colour change. Drying Technology, 18, 907-936.

Clegg, K. M., \& Morton, A. D. (1965). Carbonyl compounds and the nonenzymic browning of lemon juice. Journal of the Science of Food and Agriculture, 16, 191-196.

Contreras, C., Martín-Esparza, M. E., Chiralt, A., \& MartínezNavarrete, N. (2008). Influence of microwave application on convective drying: effects on drying kinetics, and optical and mechanical properties of apple and strawberry. Journal of Food Engineering, 88, 55-64.

Cui, Z., Li, C., Song, C., \& Song, Y. (2008). Combined microwavevacuum and freeze drying of carrot and apple chips. Drying Technology, 26, 1517-1523.

Dueñas, M., Hernándes, T., \& Estrella, I. (2007). Influence of the action of exogenous enzymes on the polyphenolic composition of pea: effect on the antioxidant activity. European Food Research and Technology, 225, 493-500.

Erenturk, S., Gulaboglu, M. S., \& Gultekin, S. (2004). The thin-layer drying characteristics of rosehip. Biosystem Engineering, 89, 159-166.

Figiel, A. (2010). Drying kinetics and quality of beetroots dehydrated by combination of convective and vacuum-microwave methods. Journal of Food Engineering, 98, 461-470.

Flink, J. M. (1983). Nonenzymatic browning of freeze-dried sucrose. Journal of Food Science, 48, 539.

Fourie, P. C., Hansmann, C. F., \& Oberholzer, H. M. (1991). Sugar content of fresh apples and pears in South Africa. Journal of Agricultural and Food Chemistry, 39, 1938-1939.

Funebo, T., \& Ohlsson, T. (1998). Microwave-assisted air dehydration of apple and mushroom. Journal of Food Engineering, 38, 353367.

Gao, X., Ohlander, M., Jeppsson, N., Björk, L., \& Trajkovski, V. (2000). Changes in antioxidant effects and their relationship to phytonutrients in fruits of sea buckthorn (Hippophae rhamnoides L.) during maturation. Journal of Agricultural and Food Chemistry, 48, 1485-1490.

Guyot, S., Marnet, N., Laraba, D., Sanoner, P., \& Drilleau, J. F. (1998). Reversed-phase HPLC following thiolysis for quantitative estimation and characterization of the four main classes of phenolic compounds in different tissue zones of a French cider apple variety (Malus domestica Var. Kermerrien). Journal of Agricultural and Food Chemistry, 46, 1698-1705.

Hamauzu, Y., Kume, C., Yasuri, H., \& Fujita, T. (2007). Reddish coloration of Chinese quince (Pseudocydonia sinensis) procyanidins during heat treatment and effect on antioxidant and antiinfluenza viral activities. Journal of Agricultural and Food Chemistry, 55, 1221-1226.

Hammami, C., René, F., \& Marin, M. (1999). Process-quality optimization of the vacuum freeze-drying of apple slices by the response surface method. International Journal of Food Science and Technology, 34, 145-160. 
Heras-Ramírez, M. E., Quintero-Ramos, A., Camacho-Dávila, A. A., Barnard, J., Talamás-Abbud, R., Torres-Muñoz, V., \& SalasMuñoz, E. (2012). Effect of blanching and drying temperature on polyphenolic compound stability and antioxidant capacity of apple pomace. Food Bioprocess Technology, 5, 2201-2210.

Hills, B. P., \& Remigereau, B. (1997). NMR studies of changes in subcellular water compartmentation in parenchyma apple tissue during drying and freezing. International Journal of Food Science and Technology, 32, 51-61.

Huang, L. L., Zhang, M., Wang, L. P., Mujumdar, A. S., \& Sun, D. F. (2012). Influence of combination drying methods on composition, texture, aroma and microstructure of apple slices. LWT-Food Science and Technology, 47, 183-188.

Kaensup, W., Chutima, S., \& Wongwises, S. (2002). Experimental study on drying of chilli in a combined microwave-vacuumrotary drum dryer. Drying Technology, 20, 2067-2079.

Kanner, J., Harel, S., Fishbein, Y., \& Shalom, P. (1981). Furfural accumulation in stored orange juice concentrates. Journal of Agricultural and Food Chemistry, 29, 948-949.

Kaya, A., Aydin, O., \& Demirtaș, C. (2007). Drying kinetics of red delicious apple. Biosystems Engineering, 96, 517-524.

Khin, M. M., Zhou, W., \& Yeo, S. Y. (2007). Mass transfer in the osmotic dehydration of coated apple cubes by using maltodextrin as the coating material and their textural properties. Journal of Food Engineering, 81, 514-522.

Krokida, M. K., \& Maroulis, Z. B. (1999). Effect of microwave drying on some quality properties of dehydrated products. Drying Technology, 17(3), 449-466.

Le Bourvellecm, C., Quéré, J. L., Sanoner, P., Drilleau, J., \& Guyot, S. (2004). Inhibition of apple polyphenol oxidase activity by procyanidins and polyphenol oxidation products. Journal of Agricultural and Food Chemistry, 52, 122-130.

Leite, J. B., Mancini, M. C., \& Borges, S. V. (2007). Effects of drying temperature on the quality of dried bananas cv. prate and d'água. LWT-Food Science and Technology, 40, 319-323.

Lewicki, P. P., \& Lukaszuk, A. (2000). Effect of osmotic dewatering on rheological properties of apple subjected to convective drying. Journal of Food Engineering, 45, 119-126.

Lim, Y. Y., \& Murtijaya, J. (2007). Antioxidant properties of Phyllanthus amarus extracts as affected by different drying methods. LWT-Food Science and Technology, 40, 1664-1669.

Oleszek, W., Lee, C. Y., Jaworski, A. W., \& Price, K. R. (1988). Identification of some phenolic compounds in apples. Journal of Agricultural and Food Chemistry, 36, 430-432.

Pal, U. S., Khan, M. K., \& Mohanty, S. N. (2008). Heat pump drying of green sweet pepper. Drying Technology, 26, 1584-1590.

Robertson, G. L., \& Samaniego, C. M. L. (1986). Effect of initial dissolved oxygen levels on the degradation of ascorbic acid and the browning of lemon juice during storage. Journal of Food Science, 51, 184-187.

Sacilik, K., \& Elicin, A. K. (2006). The thin layer drying characteristics of organic apple slices. Journal of Food Engineering, 73, 281-289.

Samotus B. (1988) Saccharides. In: Chemia żywności Z.E. Sikorski, B. Drozdowski, B. Samotus, M. Pałasiński(Ed.). PWN, Warszawa. pp. 37-128.
Sanoner, P., Guyot, S., Marnet, N., Molle, D., \& Drilleau, J. F. (1999). Polyphenol profiles of French cider apple varieties (Malus domestica sp.). Journal of Agricultural and Food Chemistry, 47, 4847-4853.

Sham, P. W. Y., Scaman, C. H., \& Durance, T. D. (2001). Texture of vacuum microwave dehydrated apple chips as affected by calcium pretreatment, vacuum level, and apple variety. Journal of Food Science, 66(9), 1341-1347.

Simal, S., Deyá, E., Frau, M., \& Rossello, C. (1997). Simple modeling of air drying curves of fresh and osmotically pre-dehydrated apple cubes. Journal of Food Engineering, 33, 139-150.

Soysal, Y., Ayhan, Z., Eştürk, O., \& Arıkan, M. F. (2009). Intermittent microwave-convective drying of red pepper: drying kinetics, physical (colour and texture) and sensory quality. Biosystem Engineering, 103, 455-463.

Szczesniak, A. S. (2002). Texture is a sensory property. Food Quality and Preference, 13, 215-225.

Szczesniak, A. S., \& Kahn, E. L. (1971). Consumer awareness of attitudes to food texture: adults. Journal of Texture Studies, 2, 280-295.

Tatum, J. H., Shaw, P. E., \& Berry, R. E. (1969). Degradation products from ascorbic acid. Journal of Agricultural and Food Chemistry, $17,38-40$.

Timoumi, S., Mihoubi, D., \& Zagrouba, F. (2007). Shrinkage, vitamin $\mathrm{C}$ degradation and aroma losses during infra-red drying of apple slices. LWT-Food Science and Technology, 40, 1648-1654.

Toğrul, H. (2005). Simple modelling of infrared drying of fresh apple slices. Journal of Food Engineering, 71, 311-323.

Tregunno, N. B., \& Goff, H. D. (1996). Osmodehydro freezing of apples: structural and textural effects. Food Research International, 29, 471-479.

Tsao, R., Yang, R., Young, J. C., \& Zhu, H. (2003). Polyphenolic profiles in eight apples cultivars using high-performance liquid chromatography (HPLC). Journal of Agricultural and Food Chemistry, 51, 6347-6353.

Velić, D., Planinić, M., Tomas, S., \& Bilić, M. (2004). Influence of air flow velocity on kinetics of convection apple drying. Journal of Food Engineering, 63, 97-102.

Wang, J., \& Chao, Y. (2002). Drying characteristics of irradiated apple slices. Journal of Food Engineering, 52, 83-88.

Wang, Z., Sun, J., Chen, F., Liao, X., \& Hu, X. (2007). Mathematical modelling on thin layer microwave drying of apple pomace with and without hot air pre-drying. Journal of Food Engineering, 80, 536-544.

Wedzicha, B. L. (1981). Sulfur dioxide: The reaction of sulfite species with food components. Nutrition and Food Science, 11/12, 14.

Yen, G. C., \& Chen, H. Y. (1995). Antioxidant activity of various tea extracts in relation to their antimutagenicity. Journal of Agricultural and Food Chemistry, 43, 27-32.

Yen, G. C., \& Huang, C. Y. (2000). Effects of alkaline and heat treatment on antioxidative activity and total phenolics of extracts from Hsian-tao (Mesona procumbens Hemsl.). Food Research International, 33, 487-492.

Zheng, H., Hwang, I., \& Chung, S. (2009). Enhancing polyphenol extraction from unripe apples by carbohydrate-hydrolyzing enzymes. Journal of Zhejiang University. Science. B, 10, 912-919. 